\begin{tabular}{l} 
Year:4, Volume:4, Number:7 / 2020 \\
\hline $\begin{array}{l}\text { The } \\
\text { Sournal of } \\
\text { Science } \\
\text { Science }\end{array}$
\end{tabular}

DOI Number: $10.30520 /$ tjsosci.667210

\title{
GLOBALIZATION, CREOLE CULTURE AND CITIES IN THE RELUCTANT FUNDAMENTALIST
}

\author{
Cengiz KARAGÖZ ${ }^{1}$
}

\begin{abstract}
Globalization is one of the most discussed issues as a mobility which has world-wide effects nearly on all of the world nations. As soon as globalization has emerged and been discussed for several decades, local cultures and creole cultures have also been studied as a result of controversies on interaction between globalization and localization. Mohsin Hamid's fiction can be examined through the global and local cultures which cannot be separated from identities of individuals and cities that seem to be the basic carriers of cultural values. In The Reluctant Fundamentalist, he deals with the conception of creole culture and dilemma of a Pakistani immigrant in America and also changing milieu of both New York and Lahore in which globalization enters a contesting process with the local structures. Conceivably believing that there is not any obvious line between the global and the local spheres, the writer displays cultural consequences of globalization which do not signify any homogenization or clash for cultural identities of cities and individuals.
\end{abstract}

Keywords: Mohsin Hamid, Globalization, Creole Culture, Global, Local, Global Cities,

\section{INTRODUCTION}

For several decades, world nations have witnessed and experienced that nearly all of them have the opportunity to communicate with and know each other much better via high-tech telecommunication tools than they did before, which has left various world-wide impacts on the structure of economic, cultural and political aspects of their lives both collectively and individually. Recently, scholars of social sciences have placed this issue in the central position of their argument concerning whether this development and process can be seen constructive or destructive for humanity. This raises the question of globalization as a mobility that breaks down barriers between countries, societies and cultures almost across the world.

One of the most ambiguous sides of discussions on globalization is concerned with who plays the dominant role in dissemination of certain imperialistic ideas and products across the world or whether globalization is felt evenly and identically in each nation. For example, Pieterse, implying that one of the theories on globalization hinges upon the potential power of the imperialist Western world, claims: "In either conceptualization, whether centred on capitalism or modernity, globalization begins in and emanates from Europe and the West. In effect, it is a theory of westernization by another name, which replicates all the problems associated with Eurocentrism..." (2009: 67). According to this view, European nations aim to dominate the rest of the world through media and other international organizations by spreading their

\footnotetext{
${ }^{1}$ Dr. Lect., Namık Kemal University, School of Foreign Languages, ckaragoz@nku.edu.tr
} 
ideological and commercial products and eliminating other nations' cultural and traditional values. Thinking that globalization cannot be attributed solely to European countries since Europe is not a single world power in many aspects, Featherstone discusses that "One perspective on the process of globalization which was accorded a good deal of credibility until recently was that of Americanization." (2005: 170). Then, one of the possibilities in the globalization process is that Europe and America are contesting or operating together in the world arena so as to preserve their imperialist policies in the Eastern nations under some surface discourses such as economic and political cooperation for humanity and a peaceful globalized world. They want to establish a world in which non-Western cultural and traditional patterns no more exist due to the rapid spread of imperialist notions all over the world.

The second notion concerning the development and results of globalization focuses on the following idea: "Impinging global influences can also lead to a revitalization of indigenous cultural forms" (Berger, 2002: 10). This possibly stems from the fact that local societies and governments feel threatened by the rapid domination of the global cultural forms which they think will cause indigenous idiosyncrasies and local values to become extinct owing to the irresistible influx of the global products and norms into their native territory. Therefore, the only way of preventing their indigenous cultural essence from vanishing and being forgotten is to revive these values more firmly and commonly by providing stores and centers that sell local products in order to remind the naive society of their local cultures. Regarding "the deglobalizing reactions to global compression and the intensity of global flows, it would be expected that the generation of such nationalistic, ethnic and fundamentalist reactions to globalization could also entail a strong assertion of local cultures" (Featherstone, 2005: 177). According to such a view of globalization, it can be possible to restructure the local cultural identities in their original forms by adhering to the local products and consuming them instead of the global ones and to encourage the local citizens to return to their peculiar cultural norms in order to indicate anti-global reactions to the Western attempts.

Another view which arises as opposed to the former ones involves the perception that globalization does not simply mean that the Western outlook will make the local cultures disappear in the future and construct a sort of world in which there will be only the global or Western forms and styles and that local revival will be achieved in its original form without any global effects. As Appadurai puts it, "Globalization does not necessarily or even frequently imply homogenization or Americanization, and to the extent that different societies appropriate the materials of modernity differently, there is still ample room for the deep study of specific geographies, histories, and languages." (2005: 17). From this approach, it can be noticed that while focusing on the route and development of globalization, scholars need to keep in mind that responses of local societies and cultures to the global forces and means cannot be overlooked and that globalization cannot be thought to consist of merely what the Western nations produce and arrange for the rest of the world. In this kind of globalization, an interaction between the global and the local appears as a result of reassertion of local traditions in such a way that "[c]ultures are borrowing, diversifying, connecting" (Wise, 2008: 27). During this interaction and interdependence, not a hierarchical relationship can be discerned because the outcome of meeting of the global and the local becomes so unpredictable that it does not seem likely to ascertain which would assume the dominant role and which would play the subordinate one in this process. As the roles become changeable and not stable in globalization, the global culture sometimes assumes the subordinate part after being restructured and reproduced by the local landscapes whereas the local elements 
turn out to be dominant and fundamental as soon as the Western products are introduced into them, which would occasionally become reversed as well.

\section{Cultural Aspect of Globalization in The Reluctant Fundamentalist}

In The Reluctant Fundamentalist, Mohsin Hamid reflects "America as transcultural space in which different cultures reflect and refract each other" and as a landscape in which South Asian citizens look at this country through their distinctive lens of both Eastern and American civilization and in which they begin to comprehend the American imperialist policies toward their homeland more clearly (Gray, 2011: 90-91). The novel also deals with the hard conditions that Muslims communities in America have to witness and endure after 9/11 attacks especially by being seen as potential terrorists and threats for the country in spite of being innocent. Besides these viewpoints, the novel can be interpreted in terms of globalization and its effects on the local identities of Eastern immigrants in America and on the metropolitan cities as well as the prospect of preserving local cultures in the face of the global forces. The reader can find certain answers as regards whether the world nations verge on cultural homogenization because of the Western or American indirect pressures on excolonized countries via a variety of means such as international corporations and serial productions of some products for eating and clothing, or this homogenization will always remain in theory not in practice as a result of persistence of local cultures in displaying their re-emergence and coexistence with the global culture.

The writer makes it clear that globalization has been felt not only by individuals but by cities as well since its penetration into many parts of the world, particularly once colonized nations, encompasses architectural traits and urbanization tendencies of cities which cannot be thought as irrelevant to the cultural character of a nation and civilization. Not consisting of only buildings, streets and other physical entities, cities embody the general and distinctive properties of a nation through their historical artifacts displaying the world views of a society and its historical development among other nations. Then, when one looks at buildings and architecture of a city carefully, he or she will probably know and notice preferences of a society as well as its priorities and peculiar conventions, which make cities possess their spirit and essences rather than concrete and aesthetic sceneries.

The writer implies the idea that cities cannot remain unaffected in their pure forms and structures in this global era, being established in accordance with the current global and Western tendencies. In the last several decades, as Taylor et al. puts it, "transport and communication/computing technologies have been fostering an intensification, expansion and extension of inter-city relations. In this way cities have become central to how many people understand contemporary globalization." (2007: 13). Therefore, it is not accidental to observe that many metropolitan cities in the world have had in common a lot through the global networks and interaction among each other. It is emphasized in the novel as follows:

\footnotetext{
You will have noticed that the newer districts of Lahore are poorly suited to the needs of those who must walk. In their spaciousness - with their public parks and wide, tree-lined boulevards they enforce an ancient hierarchy that comes to us from the countryside: the superiority of the mounted man over the man on foot. But here, where we sit, and in the even older districts that lie between us and the River Ravi - the congested, maze-like heart of this city - Lahore is more democratically urban. Indeed, in these places it is the man with four wheels who is forced to dismount and become part of the crowd. (Hamid, 2013: 36)
}

While narrating the changing structure of Lahore in which automobiles and other modern transportation vehicles are prevalent, the writer compares the contemporary scene of Lahore with its previous features, and thus concluding that the city is arranged according to the 
society's latest needs regardless of what the traditional people who walk and not use any automobiles have or demand. After moving to New York, the narrator Changez does not feel like an outsider or stranger because metropolitan cities with their similar architecture and global reflections lead immigrants to think that they do not reside in a foreign and unfamiliar land, which is mentioned in the novel: "Like Manhattan? Yes, precisely! And that was one of the reasons why for me moving to New York felt - so unexpectedly - like coming home" (Hamid, 2013: 36). When it is regarded that New York is a well-known city that possesses skyscrapers, concrete constructions, automobiles, fast food and clothing styles which are seen to exist commonly nearly in all of the big cities in the world, the fact that Changez does not feel alienated and strange does not seem so surprising. However, this does not prove that Lahore can disengage itself from its historical and traditional aspect and be overshadowed by the impacts of globalization at various levels including its spiritual structure.

Despite these changes occurring as a result of globalization in Lahore, the author also makes references to the city's older buildings that underline the esteemed properties of its civilization, comparing the city with New York's historical vision in which a rich culture and history are not present while Lahore has its own grand and stately buildings which disclose a kind of distinctiveness and supremacy:

We built the Royal Mosque and the Shalimar Gardens in this city, and we built the Lahore Fort with its mighty walls and wide ramp for our battle-elephants. And we did these things when your country was still a collection of thirteen small colonies, gnawing away at the edge of a continent. (Hamid, 2013: 116)

In addition to Lahore's global experiences that embrace higher buildings, shopping centres, newer streets and structures which do not resemble the city's older structures in any way, it on the other side displays an anti-global atmosphere where a long history and indigenous values reappear to the contemporary citizens. Even though Lahore seems very subordinate and dominated by the Western civilization in the globalization process, this lesser status turns into a dominant and supreme one once the narrator recalls the city's historical monuments reflecting Pakistani cultural values and New York's colonial times in which it did not possess such awe-inspiring monuments and structures. Consequently, Lahore hosts two dissimilar and contesting visions that appear as coexisting worlds in a single city being able to escape from neither Pakistani nor Western culture and architecture. Hence, especially metropolitan cities in the world can be "conceptualized as local sites of cultural appropriation, accommodation, and resistance to 'global conditions' as experienced, interpreted, and understood in the everyday lives of ordinary people and mediated by the social networks in which they are implicated" (Smith, 2002: 119). Lahore, like other capitals and big cities, seems to be this sort of setting which prompts the native citizens to experience both a combination and opposition when they look at its structural features in detail.

The novel questions the perception that globalization has flowed into the Eastern nations in a constant and one-sided way whereas the Western world has not been influenced by cultures and traditions of Asia and other ex-colonized countries since the beginning of the global mobility. By means of immigration movements from once colonized nations to the Western metropolitan cities, the Eastern civilization and local customs have had the chance of invading the central sites of Europe and America by reversing the colonial period where the colonialist powers invaded the Eastern world through their attempts to infiltrate the colonies with the Western cultural products (Morley and Robins, 2002: 114). By introducing their indigenous cultural products into the American territory and metropolitan centre, immigrants of once 


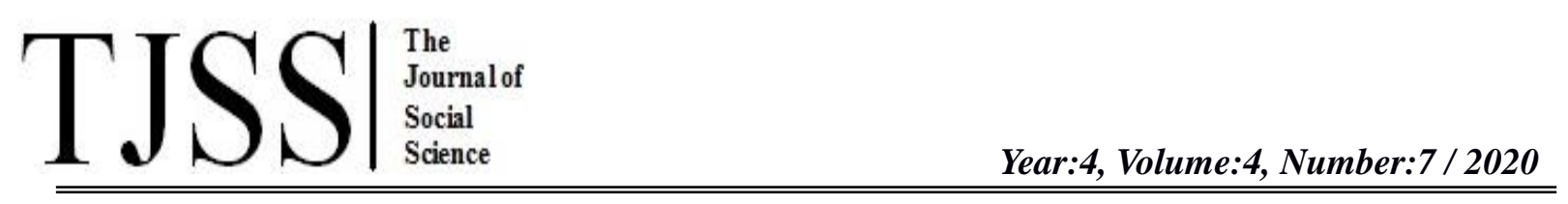

colonized nations have struck back while the imperial centre New York has had to tolerate such an introduction and retaliation. In the novel, it is mentioned that:

But there were other reasons as well: the fact that Urdu was spoken by taxicab drivers; the presence, only two blocks from my East Village apartment, of a samosa- and channa-serving establishment called the Pak-Punjab Deli; the coincidence of crossing Fifth Avenue during a parade and hearing, from loudspeakers mounted on the South Asian Gay and Lesbian Association float, a song to which I had danced at my cousin's wedding. (Hamid, 2013: 36-37)

The narrator denotes the presence of Pakistani culture and customs being revitalized in New York in which American cultural products exist more commonly as well.

Globalization for the author, thus, possibly does not amount to merely the penetration of American culture into Pakistan and working together with Pakistani culture in the cities like Lahore; instead, it also has to do with the idea that New York embodies the impacts of the global flows on a variety of aspects in its citizens' lives. As the global movement and travelling have generated a growing middle and upper class of immigrants in the United States, this new emergent class "has an easier access to the materiality of homeland culture via foods, places of worship, etc." (Rajan and Sharma, 2006: 4). As a landscape which accommodates diverse nationalities from Pakistan, India, China, Africa, and so on, America becomes a site where cultures and traditions of such nations are produced and exhibited to both native people and Western citizens. Immigration of these various nations into the mainstream of the Western civilization in America brings about the emergence and production of their languages, religious ceremonies and buildings, food, clothing, music and lifestyles which are thought to disrupt so-called Western superiority. New York like other Western metropolises is about to lose the apparent authority of its cultural values and peculiarities and seems to embrace foreign cultural products and structures in its heart. Before the arrival of these immigrants, the city generally included Christian citizens who were performing their rituals in churches; however, as soon as immigrants of Islam, Hinduism and other religions entered the city in the global age, they constructed their own religious buildings and began to perform their own ceremonies. Moreover, this movement of immigration to America has outshone the popularity of McDonalds and fast food due to the production and selling of immigrants' traditional foods that attracted the attention not only of immigrants but also of American citizens. Considering that these immigrants have large and crowded families that will multiply year by year in America, the hierarchical relationship between American culture and other foreign ones will probably be destabilized and even become reversed in such a way that American lifestyles may be placed in a subordinate status in the future.

Concerning the effect of globalization on individuals' cultures and identities, the novel illustrates how some signs of the global and the local culture can be traced in an individual in a confusing and blurred manner. This state of cultural identities can be clarified through the concept of "creolization" as it makes us "freed to focus on cultures in transition, allowing us to grasp the 'in-betweens,' the ambiguous spaces where cultural boundaries blurand disappear as hierarchical categories collapse into each other." (Baron and Cara, 2011: 4). Indicating the possibility that the global and the local culture can exist side by side in speaking, eating and clothing habits of a person, the narrator of the novel is an example of individuals reflecting more than one culture in their attitudes constantly departing from one culture and tending towards another. He says that "... I did not know where I stood on so many issues of consequence; I lacked a stable core. I was not certain where I belonged - in New York, in Lahore, in both, in neither ..." (Hamid, 2013: 168). In spite of living in New York which is 
said to be one of the global centers in the world and being far away from Lahore which is thought to be one of the cities of the global peripheries in the Eastern world, Changez does not possess any sense of the centre and periphery that seem to be unchangeable and to have a static role. This ambiguity of Changez can be recognized in his attitudes and speech throughout the novel.

Living in America and having to communicate with other American citizens by means of English, Changez on the other hand uses Urdu in his dialogues whenever he meets a Pakistani person. Berger claims that "But people do not use language innocently. Every language carries with it a cultural freight of cognitive, normative, and even emotional connotations." (2002: 3). Thus, Changez becomes a carrier of cultural elements of a nation while learning and using a language like English, displaying burdens of two cultures since he already has his native language, Urdu. While communicating American citizens, he speaks English, and he speaks Urdu while communicating with Pakistani immigrants in America. English sometimes functions as the central means of communication for Changez whereas Urdu sometimes assumes the same role. Being able to speak two languages in a sense corresponds to being familiar with two cultures and being a part of these cultures, so Changez does not carry only one culture within his manners, but two cultures at the same time and exhibit them in an unstable manner. In other words, the concepts of the global and the local become so chaotic that Changez sometimes puts the global language or culture into a secondary position while elevating the local one to a primary status. Changez's situation can be explained through the global movement in which many people learn world-wide languages such as English, French and German, etc. owing to telecommunication and other ways and become bodies of more than one culture by means of these languages. After languages surpass the borders of nations and become tools of communication between individuals, it signifies the breaking of cultural borders and allows two or more cultures to enter people's lives because they serve to be "an extraordinary vehicle of self-representation and of cultural exchange - a means of establishing identity" (Montanari, 2006: 132).

Changez's way of clothing and eating also reveals a creole culture in that his habits incorporate both American and Pakistani cultural items which come into existence in a nonlinear and fragmented way. To illustrate, Changez likes eating traditional Pakistani food at the Pak-Punjab Delhi which sells that kind of food in New York. Changez says to his friend "... our food, as you have surely gathered in your time here, is something we Lahoris is take great pride in" (Hamid, 2013: 45). In spite of being accepted as one of the local cultural elements having a secondary status among the Western nations, Lahore's traditional food occasionally surpasses the boundaries of American culture for Changez, assuming its new role as a principal one that is praised and consumed with honour by him. As Hannerz discusses that "Creolization also increasingly allows the periphery to talk back" (1992: 265), the same point can be attributed to revival of Changez's Pakistani culture in America in which his culture is expected to be forgotten and eliminated among the dominant group of Western citizens. Even if traditional food of America is commonly produced and consumed in New York by both American citizens and immigrants, Changez does not lose his interest for Lahore's local food. However, when Changez's girlfriend takes him to her parents in order to introduce him to them, and when her father asks Changez if he takes alcohol, Changez says "I do, sir" (Hamid, 2013:61). Considering that nearly all of the Pakistani citizens are Muslims who often avoid taking alcohol which is against the Islamic principles, one is likely to be surprised to see that Changez drinks. Changez, thus, sets his cultural values aside by drinking something that is decreed as a sin according to his belief system, placing a Western habit in the central position of his attitudes as soon as he meets an American family. He does not follow his cultural and 
religious norms in his drinking tendencies whereas he clings to his cultural principles in his eating Pakistani local food. This inclination most possibly leads him to feel himself both an American and a Pakistani person. As Montanari argues it, "food can serve as a mediator between cultures, opening methods of cooking to all manner of invention, cross-pollination and contamination" (2006: 132).

Before going to meet Erica's parents and in trying to decide which clothes he would put on, Changez recounts that "In the end, I took advantage of the ethnic exception clause that is written into every code of etiquette and wore a starched white kurta of delicately worked cotton over a pair of jeans" (Hamid, 2013: 55). Rather than wearing a T-shirt or formal clothes which belong to only American culture, he wears a costume that involves native cultural properties of both Pakistan and America in order to attract Erica's attention. In his clothing style, Changez wants to possess a creole culture in which Pakistani and American elements are combined and in which the centre seems to be devalued and challenged by the periphery. Instead of abandoning his local identity and culture completely in the face of the Western civilization in New York, he adds the local components to the American culture, producing a new, unusual cultural identity in his daily habits and lifestyle.

\section{CONCLUSION}

As a result, Hamid's novel, The Reluctant Fundamentalist, can be discussed with reference to the global process and outcomes of globalization which have to do with world cities and cultural identities of individuals who are torn between globalization and localization. The novel handles how cities seek to protect their local structures and ancient architecture as a reaction to globalization which is thought to shape the Eastern cities in the shade of the Western culture, and this effort results in cities such as Lahore possessing both Eastern and Western values. While possessing its native historical values and identity that are embodied in its architectural monuments, Lahore seems to be adapted to the identity and values of the Western cities in a rapid way on the other side and thus becomes a city where both global and local values coexist. This type of global process is reflected as the one which also displays Eastern values' penetration into Western cities, especially New York, in which various Eastern cultural products and values are commonly presented. Thus, globalization has influenced both the Eastern and Western worlds by generating global cities in a fragmented and unstable way, leaving behind entangled cultures whose domination and subordination do not remain fixed and firm. The same can be said for cultural identities of individuals who try to preserve their native cultures and traditions while being affected by globalization which aims to impose the Western culture and civilization on once colonized nations. Individuals are drawn into creolized cultures that are formed through an ambiguous combination of the Eastern and Western cultures whose dominant role operates temporarily without any certainty. The writer reflects in an implicit way that the globalized world means the easy access to various cultures and cultural products that range between the Western (American) and the Oriental (Pakistani) ones and that culminate in the emergence of creolized formations.

\section{REFERENCES}

Appadurai, A. (2005). Modernity at Large: Cultural Dimensions of Globalization.The United States of America: the University of Minnesota Press.

Baron, R. and Cara, A. C. (2011). Creolization as Cultural Creativity. The United States of America: The University Press of Mississippi. 


\begin{tabular}{l} 
Year:4, Volume:4, Number:7/2020 \\
\hline $\begin{array}{l}\text { The } \\
\text { Social } \\
\text { Science }\end{array}$
\end{tabular}

Berger, Peter L. (2002). "The Cultural Dynamics of Globalization.” In Many Globalizations, ed. Peter L. Berger and Samuel P. Huntington,New York: Oxford University Press,p. 1-17.

Featherstone, M. (2005). "Global and local cultures." In Mapping the Futures: Local cultures, global change, ed. John Bird, Barry Curtis, Tim Putnam, George Robertson, and Lisa Tickner, London: Taylor \& Francis e-Library, p.169-188.

Gray, R. (2011). After the Fall American Literature Since 9/11. USA and UK: WileyBlackwell.

Hamid, M. (2013). The Reluctant Fundamentalist. Great Britain: Penguin Books.

Hanners, U. (1992). Cultural Complexity: Studies in the Social Organization of Meaning.New York: Columbia University Press.

Montanari, M. (2006). Food is Culture. Trans. by Albert Sonnenfeld. New York: Columbia University Press.

Morley, D. and Robins, K. (2002). Spaces of Identity. New York and London: Taylor \& Francis e-Library.

Pieterse, J. N. (2009). Globalization and Culture, Second Ed. the United States of America: Rowman\& Littlefield Publishers.

Rajan, G. and Sharma, S. (2006). "New Cosmopolitanisms: South Asians in the United States at the Turn of the Twenty-first Century." In New Cosmopolitanisms: South Asians in the US, ed. Gita Rajan and Shailja Sharma, California: Stanford University Press, p. 1-37.

Smith, M. P. (2002). "Power in Place: Retheorizing the Local and the Global." In Understanding the City, ed. John Eade and Christopher Mele, UK and USA: Blackwell Publishers, p. 109-131.

Taylor, J. Peter et al. (2007). "Introduction: cities in globalization." In Cities in Globalization, ed. Peter J. Taylor, Ben Derudder, PieterSaeyand Frank Witlox, New York: Taylor \& Francis e-Library, p. 13-19.

Wise, J. M. (2008). Cultural Globalization.USA, UK and Australia: Blackwell Publishing. 